\title{
Synthesis and Characterization of Nanostructured WC-Co/Al Powder Prepared by Mechanical Alloying
}

\author{
Ning Ma, ${ }^{1,2}$ Keke Zhang, ${ }^{1,2}$ Danqing Yin, ${ }^{1,2}$ Di Zhao, ${ }^{1}$ Zhiwei Zhu, $^{1}$ and Fuxing Ye \\ ${ }^{1}$ School of Materials Science and Engineering, Henan University of Science and Technology, Luoyang 471023, China \\ ${ }^{2}$ Henan Key Laboratory of Non-Ferrous Materials Science \& Processing Technology, Luoyang 471023, China \\ ${ }^{3}$ School of Materials Science and Engineering, Tianjin University, Tianjin 300072, China \\ Correspondence should be addressed to Ning Ma; lsxzmn@163.com
}

Received 17 April 2016; Revised 12 June 2016; Accepted 15 June 2016

Academic Editor: Mikael Motelica-Heino

Copyright (C) 2016 Ning Ma et al. This is an open access article distributed under the Creative Commons Attribution License, which permits unrestricted use, distribution, and reproduction in any medium, provided the original work is properly cited.

\begin{abstract}
Nanostructured WC-Co/Al powder was synthesized from WC-12Co powder and pure Al powder by mechanical alloying (MA). The morphology and microstructural evolution of $\mathrm{WC}-\mathrm{Co} / \mathrm{Al}$ powder were investigated by a series of characterization methods. The results showed that the $\beta$-Co phase in the initial WC-12Co powder was replaced by the $\mathrm{Al}_{x}$ Co phases (such as $\mathrm{Al}_{9} \mathrm{Co}_{2}$ and $\left.\mathrm{Al}_{13} \mathrm{Co}_{4}\right)$. As the ball milling time increased, the average grain size of WC in the WC-Co/Al powder decreased firstly and then remained at a constant value of around $40 \mathrm{~nm}$. The deposition behavior of powders sprayed by high velocity oxygen fuel (HVOF) spraying was investigated. During spraying, the WC-Co/Al powder had a better flattening than the WC-12Co powder without ball milling, which is beneficial to fabricate compact coatings with lower porosity.
\end{abstract}

\section{Introduction}

WC based cemented carbide has been widely used in geoengineering and machining fields because of its high hardness and good red hardness [1-3]. Metal Co is the most often used material as a binder of these WC based cermets. Hard WC skeleton and flexible Co binder phase ensure the WC-Co high hardness and toughness, thus ensuring the good abrasion resistance [4,5]. Fabrication of a WC-Co coating with thickness of hundreds of microns on the surface of traditional parts is an effective and economic method to improve the wear resistance and to increase the service life of parts $[6,7]$. In recent years, with the rise of nanotechnology, people look forward to preparing more superior WC-Co coatings using nanostructured powder rather than conventional powder [8-12]. However, some authors reported that the decomposition and decarbonization of nanostructured WC grains were serious during the process of spraying, resulting in a decline in wear resistance [9-12]. Therefore, optimizing the feedstock powder structure and chemical composition has become an important way to obtain excellent performance of nanostructured WC-Co based coating [13-16]. Metal Al, which has a low melting point and an unfilled $3 \mathrm{pl}$ orbital, also can be used as a binder of WC based cermets [17]. Recently, Wu et al. [18] reported an Al/WC composite coating prepared by high energy milling and found that $\mathrm{Al}$ can react with WC, which was beneficial to bond $\mathrm{Al}$ and WC. Basak et al. [19] also reported that $\mathrm{Al}$ alloying can improve the wear resistance of the WC-Co coatings. However, there is still no evidence in literature regarding the deposition behavior of nanostructured WC-Co/Al powder and the details of the microstructural evolution during preparation of these powders.

In this work, a nanostructured WC based composite powder was synthesized using mechanical alloying (MA) method through adding the metal $\mathrm{Al}$ powder to the WC$12 \mathrm{Co}$ powder. Afterward, the laboratory-made $\mathrm{WC}-\mathrm{Co} / \mathrm{Al}$ powders were sprayed onto mild steel by high velocity oxygen fuel (HVOF) spraying. Morphology, microstructure, phase constitution, and deposition behavior of the powders were investigated using a series of characterization methods.

\section{Materials and Experimental Methods}

2.1. Materials. Commercially available WC-12Co powder, obtained from Zhangyuan Tungsten Industry New Materials 


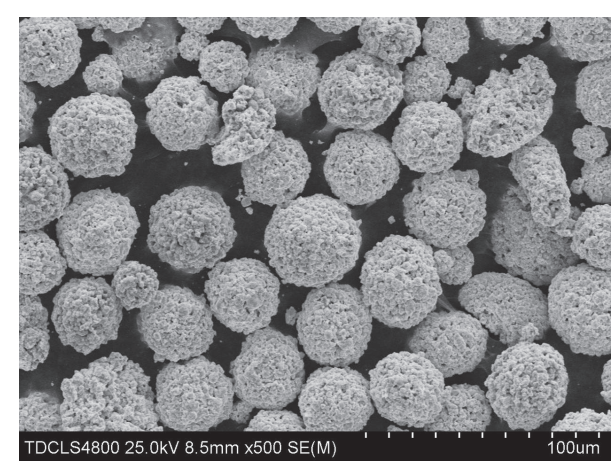

(a)

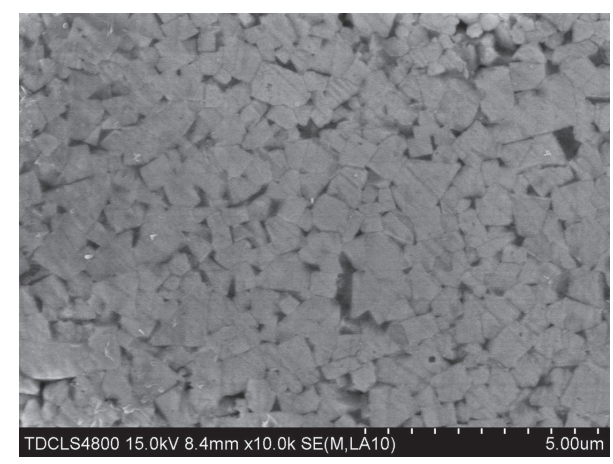

(b)

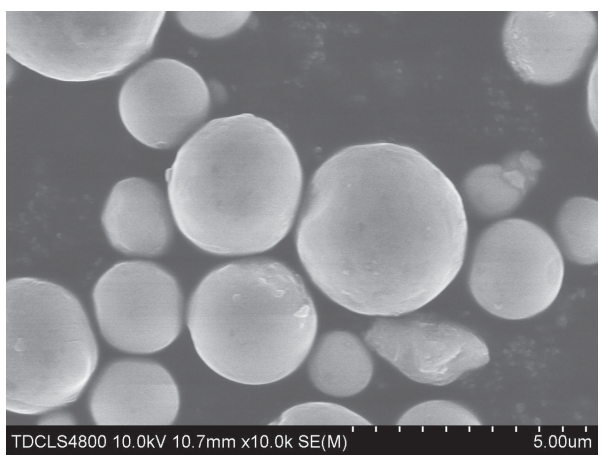

(c)

FIGURE 1: The morphology (a) and microstructure (b) of the WC-12Co powder and the morphology of the Al powder (c).

Co., Ltd., China, and pure $\mathrm{Al}$ powder, provided by Beijing General Research Institute of Mining \& Metallurgy, China, were used to prepare the WC-Co/Al composite powder. The morphology and microstructure of these powders were examined by a Hitachi S- 4800 scanning electron microscope (SEM), and the typical SEM photos are shown in Figure 1. The WC-12Co powders, which showed near-spherical shapes with rough and porous surfaces (Figure 1(a)), were fabricated by the agglomerating and sintering method. These WC-12Co particles had a size range from 15 to $45 \mu \mathrm{m}$ (Figure 1(a)). Figure 1(b) is the cross-section SEM image of WC-12Co powder. It can be seen that the WC grain size ranges from 0.2 to $1 \mu \mathrm{m}$. Figure 1(c) shows that the Al powders have a globular shape and smooth surface, and the size distribution is $-5+$ $1 \mu \mathrm{m}$.

2.2. Mechanical Alloying. The WC-12Co powder and Al powder were mixed evenly, with a mass proportion of $97: 3$, in a QM3-SP4J planetary ball mill machine. The ball milling time was $10 \mathrm{~h}, 30 \mathrm{~h}$, and $50 \mathrm{~h}$, respectively. Before ball milling, the stainless steel ball jar was vacuumized and then filled with Ar gas as shielding gas. Stearic acid $\left(\mathrm{C}_{18} \mathrm{H}_{36} \mathrm{O}_{2}\right)$ was added into the jar as a process control agent (PCA), in order to prevent the cold welding between the grinding balls, powders, and jar wall. The revolving speed of the jar was set at 500 RPM. The mass ratio of ball to powders was $10: 1$. After the ball milling, we crushed the powder manually by a mortar and pestle. Then a fine screen was used to screen the WC$\mathrm{Co} / \mathrm{Al}$ powder to a size range from 15 to $40 \mu \mathrm{m}$.
2.3. Characterization. The morphology and microstructure of powders were investigated by the Hitachi S-4800 SEM. A Bruker D8 FOCUS X-ray diffractometer (XRD, Cu-K $\alpha$ radiation, voltage $40 \mathrm{kV}$, electric current $40 \mathrm{~mA}$, and scanning speed $2^{\circ} / \mathrm{min}$ ) was used to analyze the phase structure of powders. In this work, average grain size of WC was determined by measuring the line broadening at half the maximum diffraction intensity of the WC phase $\left(2 \theta=35.6^{\circ}\right.$, $d=0.252 \mathrm{~nm}$ on the face (100)) and then was calculated using Scherrer's equation [20]:

$$
D=\frac{0.89 \lambda}{\beta_{1 / 2} \cos \theta},
$$

where $D$ is the grain size, $\lambda$ is the $\mathrm{X}$-ray wavelength $(\lambda=$ $0.15406 \mathrm{~nm}$ for $\mathrm{Cu}-\mathrm{K} \alpha$ radiation in this work), $\beta_{1 / 2}$ is the line broadening at half the maximum intensity (in radians), and $\theta$ is the Bragg angle.

A TJ-9000 HVOF spraying system (China, Tianjin University) was used to spray powders onto the mild steel plates for investigating the deposition behavior of the powders. The spraying parameters were the oxygen pressure of $0.7 \mathrm{MPa}$, the oxygen flow rate of $245 \mathrm{~L} / \mathrm{min}$, the fuel gas pressure of $0.65 \mathrm{MPa}$, the fuel gas flow rate of $30 \mathrm{~L} / \mathrm{min}$, and the spraying distance of $270 \mathrm{~mm}$, respectively. The splats were collected and the coatings were also prepared. The morphology of splats and the microstructure of coatings were investigated by the Hitachi S-4800 SEM. Porosity of coatings was measured using the metallographic method [7]. 10 cross-section images 
of each coating obtained by OLYMPUS GX51 optical microscope (OM), with a magnification of 200 times, were used for the measurement of porosity.

\section{Results and Discussion}

3.1. XRD Analysis of Powders. In this paper, a total of three sets of WC-Co/Al powder were prepared. These powders were denoted by $1 \#, 2 \#$, and $3 \#$, which corresponded to the ball milling time of $10 \mathrm{~h}, 30 \mathrm{~h}$, and $50 \mathrm{~h}$, respectively. For convenience, the initial WC-12Co powder was denoted by 0 \# powder. Figure 2 is the XRD patterns of 1\#, 2\#, and 3\# WC$\mathrm{Co} / \mathrm{Al}$ powders and the WC-12Co powder. We can see that the WC phase (PDF-ICDD: 73-0471) and the $\beta$-Co phase (PDFICDD: 15-0806) constitute the initial WC-12Co powder. The height of the WC phase diffraction peaks becomes lower and wider with the increase of milling time. This indicated that WC grains were repeatedly crushed and broken by balls, becoming smaller and smaller during the process of ball milling. The $\beta$-Co phase diffraction peak, which was detected in the initial WC-12Co powder $\left(2 \theta=44^{\circ}, d=0.205 \mathrm{~nm}\right)$, disappeared in the $\mathrm{XRD}$ patterns of $\mathrm{WC}-\mathrm{Co} / \mathrm{Al}$ powders after the ball milling. This is because of the solution of $\mathrm{Al}$ in the Co matrix. One dump was detected at the $2 \theta=45^{\circ} \sim 47^{\circ}$ in each WC-Co/Al powder instead of the sharp diffraction peak, which showed that the binding phase became amorphous to some extent during the ball milling [21]. The reason for this phenomenon can be attributed to the fact that the grinding balls repeatedly squeezed the mixed powders making the $\mathrm{Al}$ element dissolve into the Co phase and facilitating the formation of intermetallic compounds (IMCs) of $\mathrm{Al}$ and $\mathrm{Co}$, such as AlCo (PDF-ICDD: 65-0672), $\mathrm{Al}_{5} \mathrm{Co}_{2}$ (PDF-ICDD: 65-3638), $\mathrm{Al}_{9} \mathrm{Co}_{2}$ (PDF-ICDD: 65-2369), or $\mathrm{Al}_{13} \mathrm{Co}_{4}$ (PDFICDD: 65-1165) [22]. Because the diffraction peaks of these IMC phases are very closed in the XRD patterns, we noted them as $\mathrm{Al}_{x} \mathrm{Co}$ in this paper.

Figure 3 is the average WC grain size as a function of the milling time. Grain size of WC phase is a crucial factor of the microstructure of WC based powders and coatings [13]. The calculated average WC grain size of $0 \#, 1 \#, 2 \#$, and 3\# powders from (1) was $248.5 \mathrm{~nm}, 93.1 \mathrm{~nm}, 39.0 \mathrm{~nm}$, and $44.8 \mathrm{~nm}$, respectively. As we know, Scherrer's formula is only applicable to nanoscale materials [20]. When the value of $\mathrm{D}$ was larger than $100 \mathrm{~nm}$, the calculated error is great, so the result of the initial WC-12Co powder was inaccurate and presented in Figure 4 only for comparison. It can be seen from the powders' cross-section SEM images (Figure 1(b)) that the average grain size of WC-12Co powder is about 0.5 microns. The calculated values of $1 \#, 2 \#$, and $3 \# \mathrm{WC}-\mathrm{Co} / \mathrm{Al}$ powders were all lower than $100 \mathrm{~nm}$. At the early stage of the ball milling process, the WC grain size decreased sharply with the milling time due to the drastically mechanical crushing. However, when the grain refinement reached a critical level, high specific surface area increased the materials' surface energy significantly [8]. Consequently, at the subsequent milling, the average grain size of WC in the $\mathrm{WC}-\mathrm{Co} / \mathrm{Al}$ powder did not decrease further but nearly remained at a constant value of around $40 \mathrm{~nm}$. Therefore, a too long milling time is worthless.

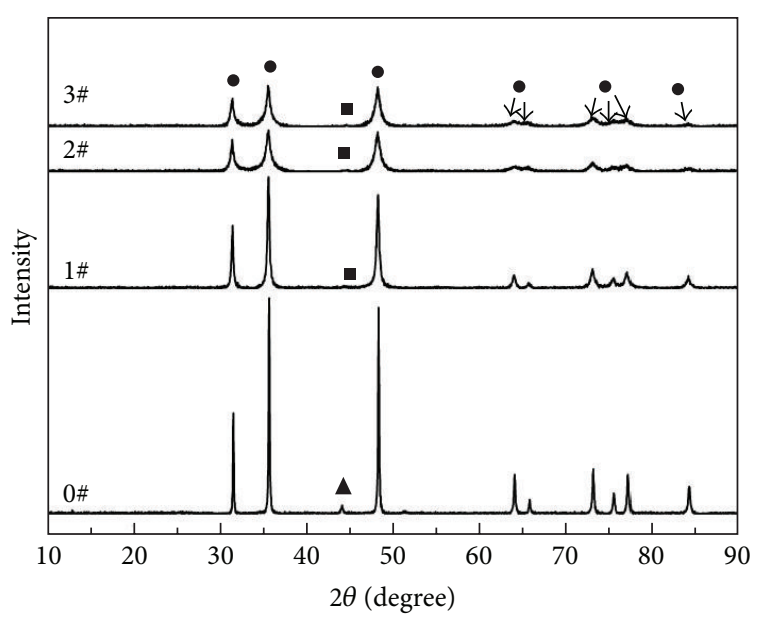
- WC
$\triangle \mathrm{Co}$
- $\mathrm{Al}_{x} \mathrm{Co}$

FIGURE 2: The XRD patterns of WC-12Co powder and WC-Co/Al powder milled of various times.

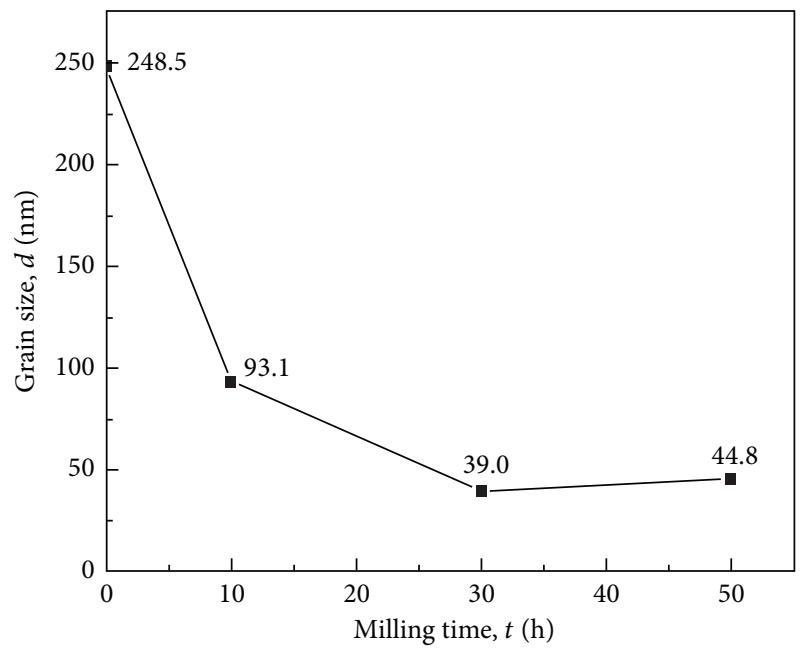

FIgURE 3: The average WC grain size as a function of the milling time.

3.2. Morphology and Microstructure of the Powders. Figure 4 shows the typical morphology and cross-section microstructure of the 2\# WC-Co/Al powder. As can be seen from Figure 4(a), the powders had a very rough surface and presented a polygonal morphology. This is the typical powder morphology after ball milling process as a result of the collision and crushing between the ball and powders [2, 8]. From Figure 4(b), we can see that the interior structure of powders is very dense with fine WC grains dispersed in the binding phase uniformly. There are almost no pores inside the powder. In addition, it can be seen that the WC grains size is very small, most of which were under $100 \mathrm{~nm}$, indicating that the calculated results from Scherrer's equation are credible. 


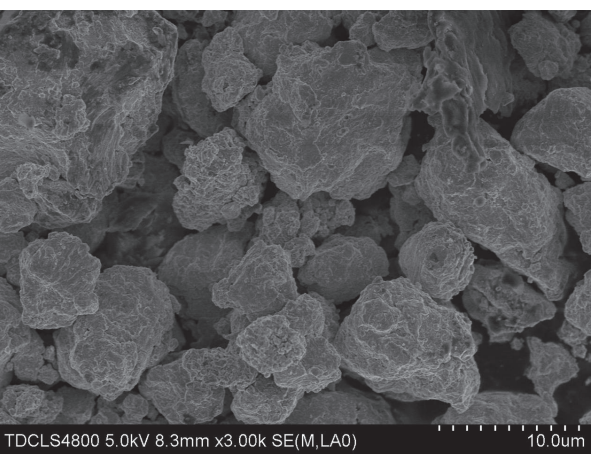

(a)

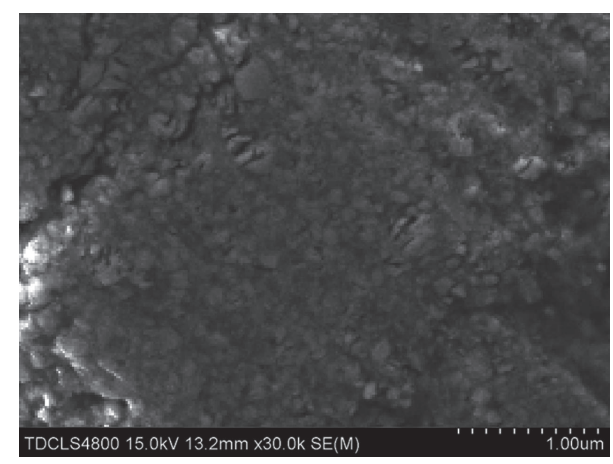

(b)

FIGURE 4: The typical morphology (a) and cross-section microstructure (b) of the WC-Co/Al powder.

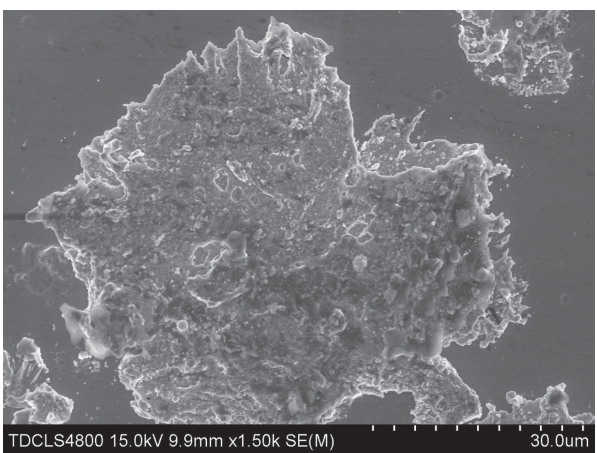

(a)

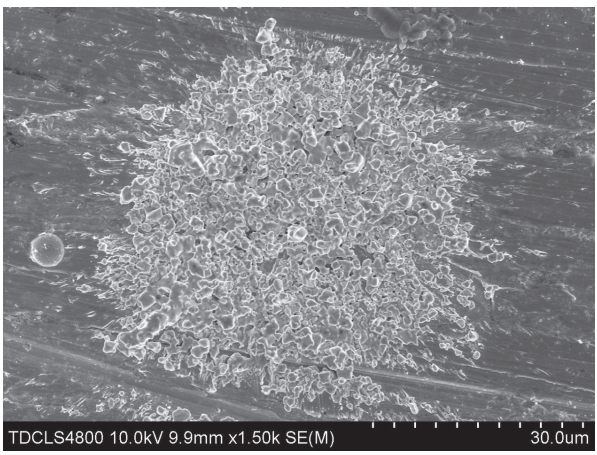

(c)

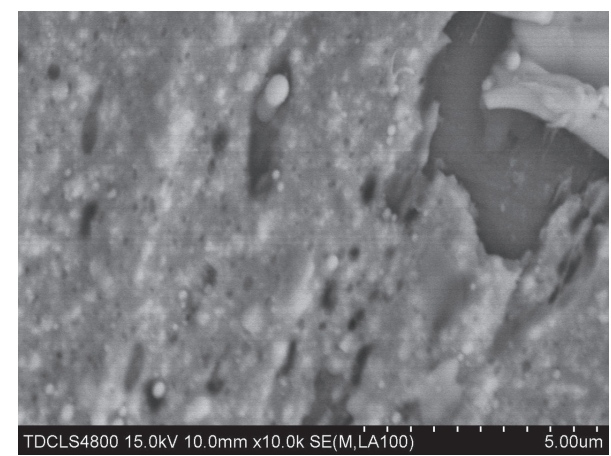

(b)

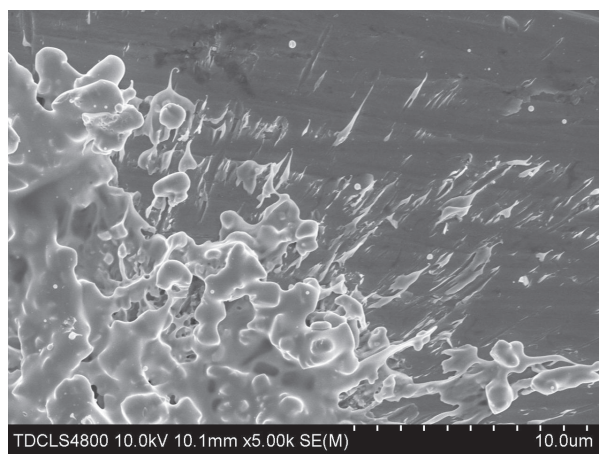

(d)

Figure 5: The HVOF deposited splats' morphology of the WC-Co/Al powder in full view (a) and in edge view (b) and the WC-12Co powder in full view (c) and in edge view (d).

3.3. Deposition Behavior of the Powders. Among these three ball-milled powders, 2\# powder had the finest WC grain size, and the ball milling time of $2 \#$ powder was moderate. Therefore, in this work, we take $2 \#$ powder as a preferred $\mathrm{WC}-\mathrm{Co} / \mathrm{Al}$ powder to prepare the splats and coatings using HVOF spraying for investigating the deposition behavior of the WC-Co/Al powders. For comparison, the WC-12Co splats and coatings were also prepared by the HVOF spraying. Figure 5 shows the HVOF deposited splats' morphology of the $2 \# \mathrm{WC}-\mathrm{Co} / \mathrm{Al}$ powder and the WC-12Co powder. It can be seen that the flattened degree of the ball-milled WC$\mathrm{Co} / \mathrm{Al}$ powder (Figures 5(a) and $5(\mathrm{~b})$ ) is better than that of
WC-12Co powder (Figures 5(c) and 5(d)). This suggested that, under the same spraying parameters, ball-milled WC$\mathrm{Co} / \mathrm{Al}$ powder was easier to spread around than the initial WC-12Co powder. Several reasons are responsible for this phenomenon. One is the finer WC grains of the $\mathrm{WC}-\mathrm{Co} / \mathrm{Al}$ powder compared with the WC-12Co powder, which can be seen clearly in Figures 5(b) and 5(d). The WC grain size of WC-12Co powder without ball milling ranged from 0.2 to $1 \mu \mathrm{m}$, while the average size of WC grains after the ball milling was only $39 \mathrm{~nm}$. Li and Yang [13] reported that the refinement of carbide grains was favorable for the carbide based powders to flatten during the HVOF spraying. In addition, $\mathrm{He}$ and 


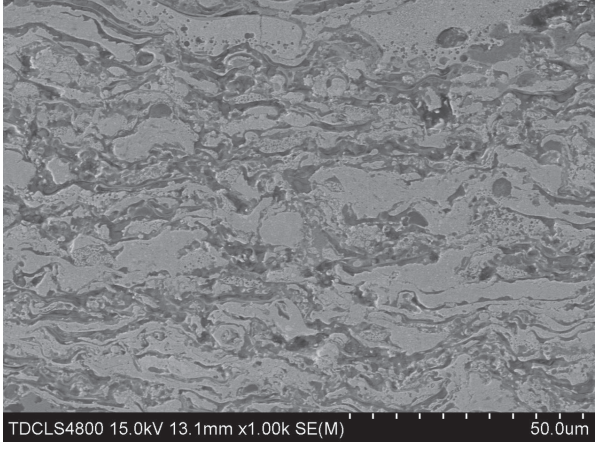

(a)

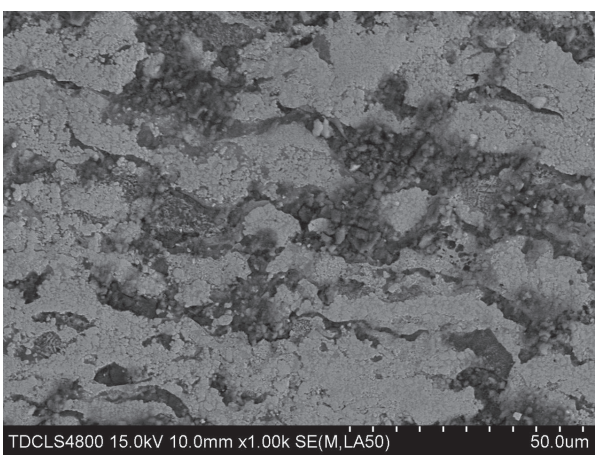

(c)

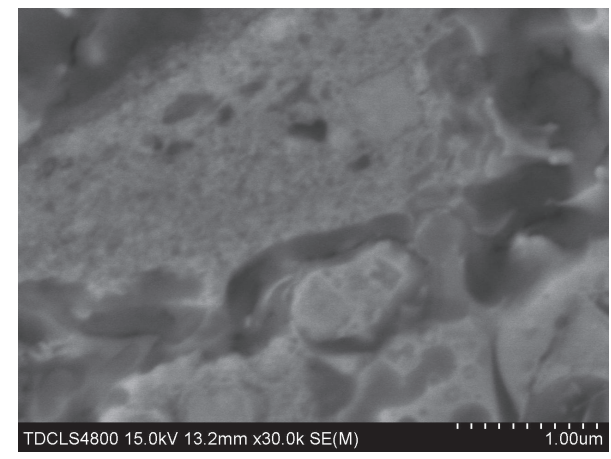

(b)

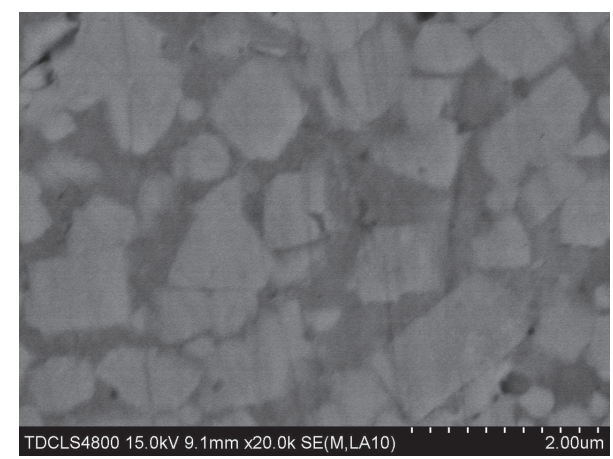

(d)

FIgURE 6: The cross-section SEM images of the WC-Co/Al coating at lower magnification (a) and higher magnification (b) and the WC-12Co coating at lower magnification (c) and higher magnification (d).

Schoenung [21] reported that, under the same condition of HVOF spraying, nanostructured WC-Co powders would experience higher temperature than the micron-structured WC-Co powders, which is also advantageous to the particle flattening. The other reason is that the aluminum has a low melting point $\left(660^{\circ} \mathrm{C}\right)$ and good thermal conductivity, making the WC-Co/Al powder easier to melt. Furthermore, comparing Figures 1(a) and 4(a) we can find that the size of $\mathrm{WC}-\mathrm{Co} / \mathrm{Al}$ powder is smaller than that of WC-12Co powder, which also makes the WC-Co/Al powder easier to melt and flatten.

The cross-section SEM images of the WC-Co/Al coating and the WC-12Co coating are shown in Figure 6. It can be seen that both the two kinds of coating have a lamellar structure, which is determined by the nature of thermally spraying process [13, 21]. HVOF spraying gun provided particles with high speed impacting to the substrate, and then the particle flattened and solidified rapidly. The subsequent particles will be gradually superimposed onto the deposited layers, and finally the coatings were prepared. However, it is worth noting that the thickness of each layer in the WC-Co/Al coating (Figure 6(a)) is thinner than that of the WC-12Co coating (Figure 6(c)). This is associated with the flattening degree of two powders, as shown in Figure 5. The $\mathrm{WC}-\mathrm{Co} / \mathrm{Al}$ powder was easier to flatten during deposition, so the thickness of splats was thinner and thus the coating got the finer microstructure. From Figure 6(c) we can see clearly that the cross-section profiles of the splats in the
WC-12Co coating are thick relatively, which also demonstrates the results observed in Figure 5(c). In the WC-Co/Al coating (Figure 6(b)), the WC grains were very fine and most of them retained nanostructure. It can be seen from Figure 6(d) that the WC grains basically remain of similar size and shape compared with that in the WC-12Co powders (Figure 1(b)). This suggested that the decomposition of WC phase is slight during the process of HVOF spraying. In addition, comparing Figure 6(a) with Figure 6(c) we can find that the WC-Co/Al coating exhibits more compact microstructure than WC-12Co coating. The porosity of WC$12 \mathrm{Co}$ coating calculated using the metallographic method was $1.62 \%$, while the porosity of nanostructured $\mathrm{WC}-\mathrm{Co} / \mathrm{Al}$ coating was only $0.57 \%$. Tillmann et al. [23] reported that the porosity of coatings decreased with the improvement of the single particles flattening. The phenomena observed in Figures 5 and 6 are in agreement with the conclusion from Tillmann et al.

\section{Conclusion}

The nanostructural WC-Co/Al powder was prepared by mechanical alloying from the pure $\mathrm{Al}$ powder and submicron-structured WC-12Co powder. During the process of ball milling, the $\mathrm{Al}$ powder reacted with the Co phase in WC-12Co powder and intermetallic compound of $\mathrm{Al}$ and $\mathrm{Co}$, noted by $\mathrm{Al}_{x} \mathrm{Co}$, generated. Ball milling time was an important factor for determining the average WC grain size. 
After milling time of $10 \mathrm{~h}, 30 \mathrm{~h}$, and $50 \mathrm{~h}$, the average $\mathrm{WC}$ grain size of WC-Co/Al powder was $93.1 \mathrm{~nm}$ and $39.0 \mathrm{~nm}$ and $44.8 \mathrm{~nm}$. During HOVF spraying, the WC-Co/Al powder had a better flattening degree than the WC-12Co powder without ball milling, which is beneficial to form a uniform and compact microstructure in the $\mathrm{WC}-\mathrm{Co} / \mathrm{Al}$ coating. The porosity of the WC-Co/Al coating, which was only $0.57 \%$, decreased significantly than that of the WC-12Co coating $(1.62 \%)$.

\section{Competing Interests}

The authors declare that there are no competing interests regarding the publication of this paper.

\section{Acknowledgments}

The authors are grateful for the financial support by the National Natural Science Foundation of China (no. 51375332).

\section{References}

[1] X. Ren, H. Miao, and Z. Peng, "A review of cemented carbides for rock drilling: an old but still tough challenge in geoengineering," International Journal of Refractory Metals and Hard Materials, vol. 39, pp. 61-77, 2013.

[2] N. Al-Aqeeli, N. Saheb, T. Laoui, and K. Mohammad, "The synthesis of nanostructured WC-based hardmetals using mechanical alloying and their direct consolidation," Journal of Nanomaterials, vol. 2014, Article ID 640750, 16 pages, 2014.

[3] T. Kagnaya, C. Boher, L. Lambert, M. Lazard, and T. Cutard, "Wear mechanisms of WC-Co cutting tools from high-speed tribological tests," Wear, vol. 267, no. 5-8, pp. 890-897, 2009.

[4] H.-O. Andrén, "Microstructures of cemented carbides," Materials and Design, vol. 22, no. 6, pp. 491-498, 2001.

[5] G. S. Upadhyaya, "Materials science of cemented carbides-an overview," Materials and Design, vol. 22, no. 6, pp. 483-489, 2001.

[6] R. J. K. Wood, "Tribology of thermal sprayed WC-Co coatings," International Journal of Refractory Metals and Hard Materials, vol. 28, no. 1, pp. 82-94, 2010.

[7] Q. Yang, T. Senda, and A. Ohmori, "Effect of carbide grain size on microstructure and sliding wear behavior of HVOF-sprayed WC-12\% Co coatings," Wear, vol. 254, no. 1-2, pp. 23-34, 2003.

[8] J. He and J. M. Schoenung, "Nanostructured coatings," Materials Science and Engineering: A, vol. 336, no. 1-2, pp. 274-319, 2002.

[9] D. A. Stewart, P. H. Shipway, and D. G. McCartney, "Microstructural evolution in thermally sprayed WC-Co coatings: comparison between nanocomposite and conventional starting powders," Acta Materialia, vol. 48, no. 7, pp. 1593-1604, 2000.

[10] D. A. Stewart, P. H. Shipway, and D. G. McCartney, "Abrasive wear behaviour of conventional and nanocomposite HVOFsprayed WC-Co coatings," Wear, vol. 225-229, part 2, pp. 789798, 1999.

[11] A. H. Dent, S. DePalo, and S. Sampath, "Examination of the wear properties of HVOF sprayed nanostructured and conventional WC-Co cermets with different binder phase contents," Journal of Thermal Spray Technology, vol. 11, no. 4, pp. 551-558, 2002.
[12] P. H. Shipway, D. G. McCartney, and T. Sudaprasert, "Sliding wear behaviour of conventional and nanostructured HVOF sprayed WC-Co coatings," Wear, vol. 259, no. 7-12, pp. 820-827, 2005.

[13] C.-J. Li and G.-J. Yang, "Relationships between feedstock structure, particle parameter, coating deposition, microstructure and properties for thermally sprayed conventional and nanostructured WC-Co," International Journal of Refractory Metals and Hard Materials, vol. 39, pp. 2-17, 2013.

[14] N. Ma, L. Guo, Z. Cheng, H. Wu, F. Ye, and K. Zhang, "Improvement on mechanical properties and wear resistance of HVOF sprayed WC-12Co coatings by optimizing feedstock structure," Applied Surface Science, vol. 320, pp. 364-371, 2014.

[15] A. K. Basak, P. Matteazzi, M. Vardavoulias, and J.-P. Celis, "Corrosion-wear behaviour of thermal sprayed nanostructured FeCu/WC-Co coatings,” Wear, vol. 261, no. 9, pp. 1042-1050, 2006.

[16] J. Yuan, Y. Zhu, X. Zheng, H. Ji, and T. Yang, "Fabrication and evaluation of atmospheric plasma spraying $\mathrm{WC}-\mathrm{Co}-\mathrm{Cu}-\mathrm{MoS}_{2}$ composite coatings," Journal of Alloys and Compounds, vol. 509, no. 5, pp. 2576-2581, 2011.

[17] A. A. Ogwu and T. J. Davies, "Electronic structure basis for selection of metal binders for hardmetal systems," Materials Science and Technology, vol. 9, no. 3, pp. 213-217, 1993.

[18] Y. Wu, X. Liu, G. Ma, C. Li, and J. Zhang, "High energy milling method to prepare Al/WC composite coatings in Al-Si alloys," Journal of Alloys and Compounds, vol. 497, no. 1-2, pp. 139-141, 2010.

[19] A. K. Basak, J.-P. Celis, M. Vardavoulias, and P. Matteazzi, "Effect of nanostructuring and $\mathrm{Al}$ alloying on friction and wear behaviour of thermal sprayed WC-Co coatings," Surface and Coatings Technology, vol. 206, no. 16, pp. 3508-3516, 2012.

[20] A. W. Burton, K. Ong, T. Rea, and I. Y. Chan, "On the estimation of average crystallite size of zeolites from the Scherrer equation: a critical evaluation of its application to zeolites with one-dimensional pore systems," Microporous and Mesoporous Materials, vol. 117, no. 1-2, pp. 75-90, 2009.

[21] J. He and J. M. Schoenung, "A review on nanostructured WCCo coatings," Surface and Coatings Technology, vol. 157, no. 1, pp. 72-79, 2002.

[22] P. Priputen, M. Kusý, M. Drienovský et al., "Experimental reinvestigation of $\mathrm{Al}-\mathrm{Co}$ phase diagram in vicinity of $\mathrm{Al}_{13} \mathrm{Co}_{4}$ family of phases," Journal of Alloys and Compounds, vol. 647, pp. 486-497, 2015.

[23] W. Tillmann, B. Hussong, T. Priggemeier, S. Kuhnt, N. Rudak, and $\mathrm{H}$. Weinert, "Influence of parameter variations on WC-Co splat formation in an HVOF process using a new beam-shutter device," Journal of Thermal Spray Technology, vol. 22, no. 2-3, pp. 250-262, 2013. 

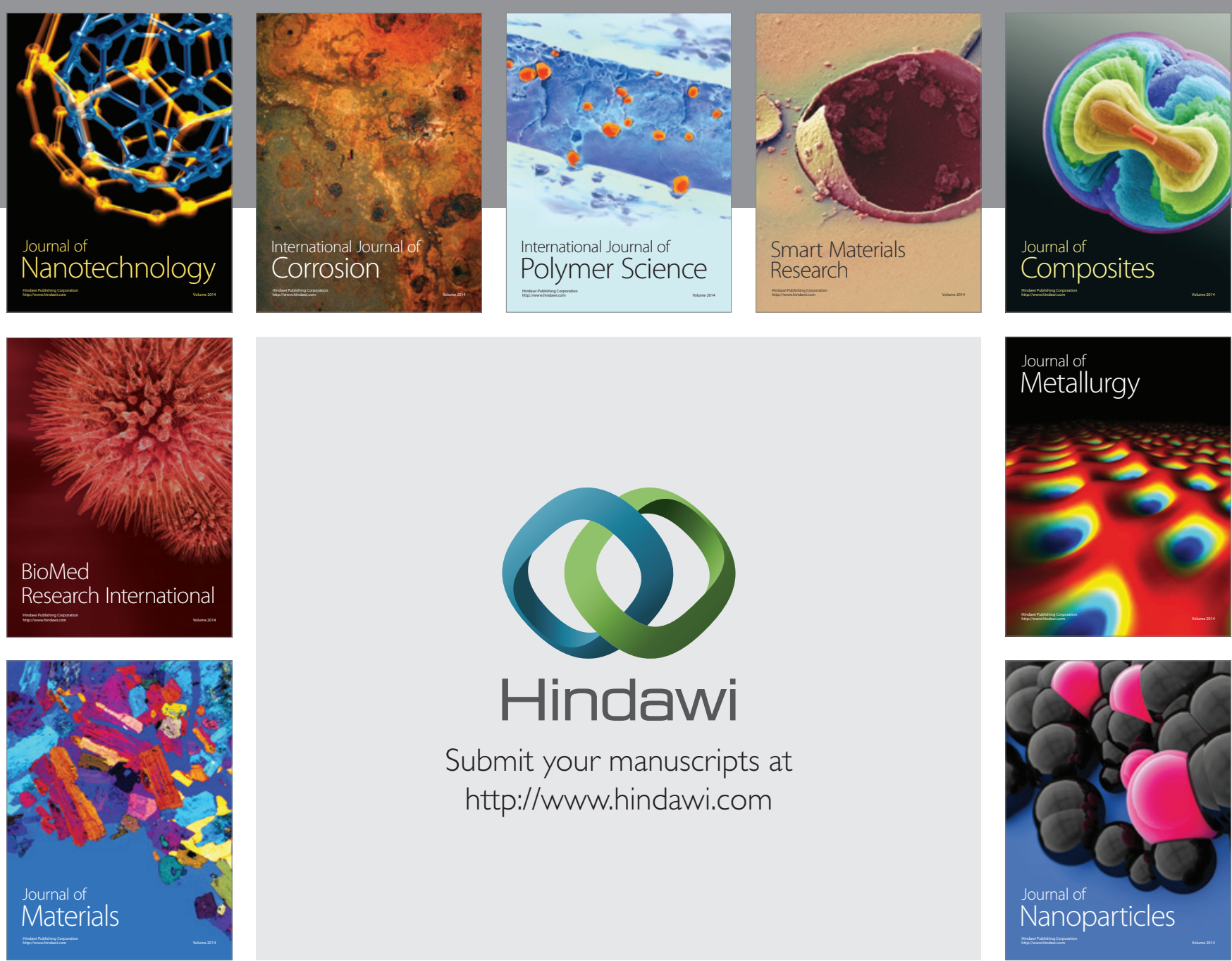

\section{Hindawi}

Submit your manuscripts at

http://www.hindawi.com

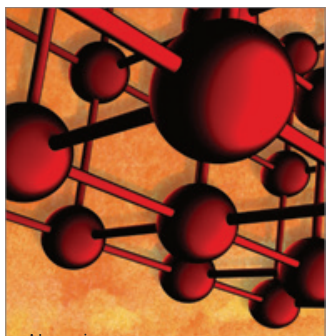

Materials Science and Engineering
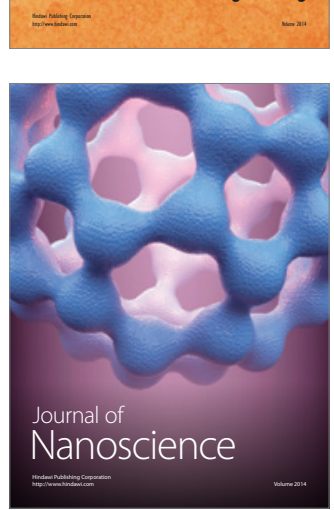
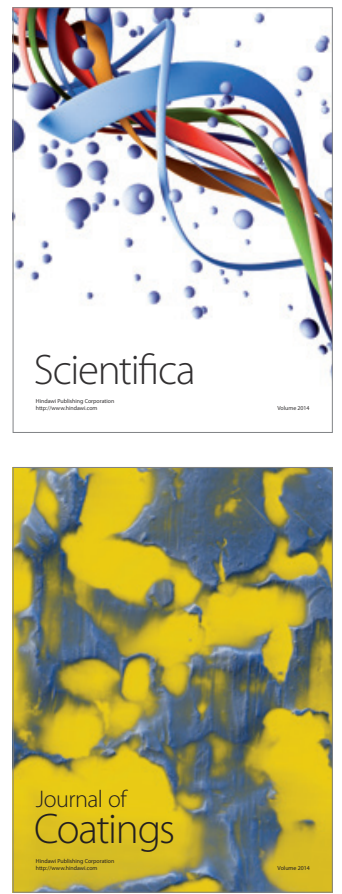
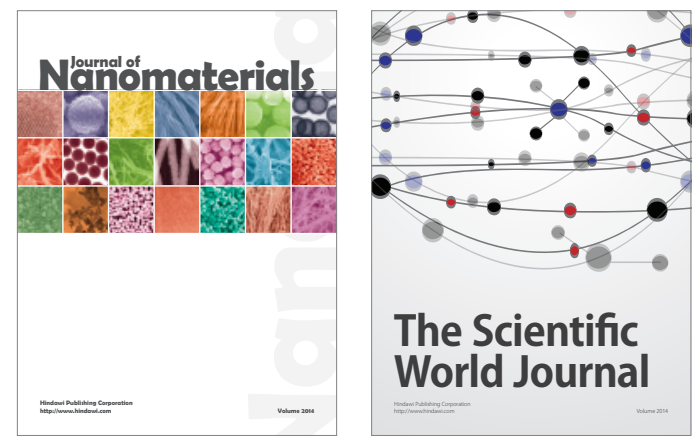

The Scientific World Journal
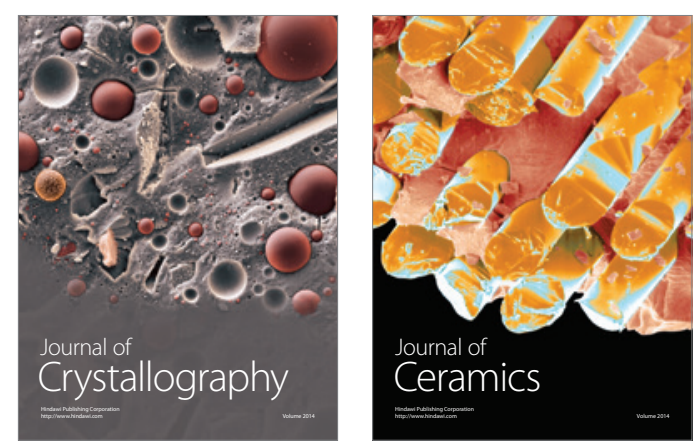
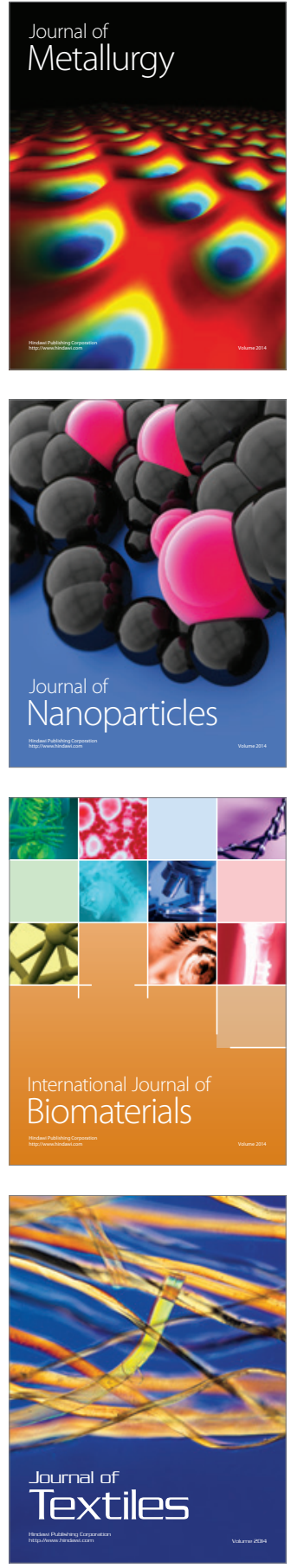